\title{
Ultrastructural Examination of Spermiogenesis and Spermatozoon Ultrastructure in Congo tetra Phenacogrammus interruptus Boulenger, 1899 (Ostariophysi: Characiformes: Alestidae)
}

\begin{abstract}
Anna PECIO
Accepted September 15, 2008

PECIO A. 2009. Ultrastructural examination of spermiogenesis and spermatozoon ultrastructure in Congo tetra Phenacogrammus interruptus Boulenger, 1899 (Ostariophysi: Characiformes: Alestidae). Folia biol. (Kraków) 57: 13-21.

Ultrastructural studies of spermiogenesis in Phenacogrammus interruptus using transmission electron microscopy revealed that the process is characterized by flagellum development, formation of a cytoplasmic canal, nuclear rotation, and nuclear fossa formation. Chromatin compaction proceeds during spermatid transformation within the spermatocysts as well as after spermiation within the lumen of the efferent ducts. The spermatozoon is of primitive type and exhibits characters typical for Type I aquasperm. The head consists of a spherical nucleus with highly condensed chromatin and a centrally located electron lucent area connected to a moderate-sized nuclear fossa. The nuclear fossa contain centrioles in perpendicular arrangement, surrounded by osmiophilic fibrous material. In the short midpiece, several mitochondria and vesicles are unevenly distributed in the cytoplasm forming the cytoplasmic collar at the base of the nucleus. The cytoplasmic collar surrounds the initial part of the flagellum, running in the cytoplasmic canal. The flagellar axoneme has a typical pattern $(9 \times 2+2)$ and the flagellum contains membranous compartments in the portion immediately posterior to the termination of the cytoplasmic canal.
\end{abstract}

Key words: Spermiogenesis, sperm ultrastructure, Characiformes, Alestidae, Phenacogrammus interruptus.

Anna PECIO, Department of Comparative Anatomy, Institute of Zoology, Jagiellonian University, R. Igardena 6, 30-060 Kraków, Poland.

E-mail:anna.pecio@uj.edu.pl
Several studies in many large groups of extant fishes have shown that morphological differences in sperm ultrastructure can be used as independent characters of taxonomic value (MATTEI 1970, 1988; JAMIESON 1991). Many fish taxa are represented by a small number of species (e.g. Halecomorphi1) and therefore the sperm morphology of one species may be representative of the entire group, even at high taxonomic rank. A completely different situation pertains to the monophyletic Teleostei, consisting of about 28000 species for which ultrastructural studies of spermatozoa have been studied in only about $1 \%$ of extant species belonging to different families (NELSON 1994; LAHNSTEINER \& PATZNER 2008). These studies have revealed that the only apomorphic character common to the spermatozoa of all neopterygians is the lack of an acrosome. On the other hand, characters such as the shape of the head region, the number, shape and distribution of mitochondria, arrangements of centrioles and their locations within or posterior to a nuclear fossa, and the number of fla- gella and axoneme structure reveal a high diversity at the subfamily and/or species level (BACCETTI 1991; JAMIESON 1991; MATTEI 1991; LAHNSTEINER \& PATZNER 2008). Sperm diversity can be explained as the result of phylogenetic inheritance, as well as adaptation to the mode of fertilization (external versus internal) and environmental circumstances at the time of gamete fusion (JAMIESON 1991; BURNS \& WEITZMAN 2005).

Data on sperm structure in Ostariophysi, a large group encompassing nearly $75 \%$ of all freshwater fishes, are known only for a limited number of species, particularly in the orders Siluriformes and Characiformes (JAMIESON 1991). The Siluriformes have a global distribution, whereas the Characiformes are distributed in Africa, South and Central America, and southern North America. New World characiforms are a speciose group comprised of 14 families and approximately 1460 species, whereas African characiforms contain only 208 species grouped in 4 families (CALCAGNOTTO et al. 2005). Phylogenetic studies on 
African characiforms revealed that they are paraphyletic and form three separate subunits: a clade consisting of the families Distichodontidae and Citharinidae, a clade formed by the monotypic Hepsetidae and a third clade, the Alestidae (GERY 1977; VARI 1979). The latter was previously included into the family Characidae as the subfamily Alestinae (GREENWOOD et al. 1966). After an evaluation of fossils and phylogenetic analysis, it was shown that the family Characidae is composed of only neotropical genera, but the Alestidae form a trans-Atlantic family within the Characiformes (GERY 1977; ZANATA \& VARI 2005). The members of the African alestids evolved independently in Africa for 90-112 million years and developed into the most diverse group of characiforms, including 105 species, ranging from the diminutive species of Virilia to the large tiger fish, Hydrocynus goliath (ZANATA \& VARI 2005).

Sperm structure among characiforms has now been studied in several genera belonging mostly to the neotropical fish fauna, e.g. in Erythrynidae (QUAGIO-GRASSIOTTO et al.2001a), Curimatidae (QUAGIO-GRASSIOTTO et al. 2003), Anostomidae (PECIO 2003) and several species of Characidae, both from subfamilies with external and internal fertilization (BURNS et al. 1995, 1998; PECIO \& RAFIŃSKI 1999; ROMAGOSA et al. 1999; ANDRADE et al. 2001; PECIO et al. 2005, 2007; VERISSIMOSILVEIRA et al.2006). Among African characiformes, spermatozoon structure has been described in one Citharinus sp. of the Citharinidae (MATTEI et al. 1995) and in Alestes dentex of the Alestidae, in which the spermiogenesis was analyzed (SHAHIN 2006a). For other alestids, Micralestes sp. and Phenacogrammus interruptus, the similarity to A. dentex spermatozoon in centrioles arrangement in nuclear fossa was indicated by BURNS et al. (in press).

The main purpose of the present study is to provide information on spermiogenesis and sperm structure in the externally fertilizing species $P$. interruptus for a comparison with sperm structure of A. dentex and other species of Characiformes. This information will contribute to the growing database of ultrastructural characters that are being used in hypothesizing phylogenetic relationships among characiform species (WEITZMAN \& MALABARBA 1998).

\section{Material and Methods}

The natural population of the Congo tetra, Phenacogrammus interruptus Boulenger, 1899, inhabits large areas of the Congo river system. This species is one of the most popular, colorful and commonly available African tetra. The males for this study were obtained from a local aquarist. Animals were kept under a natural photoperiod in an aquarium $(80 \times 45 \times 40 \mathrm{~cm})$ for several months prior to examination and fed daily ad libitum with small crustaceans and Tubifex worms. Mature males of total length $70-77 \mathrm{~mm}$ were killed by over-anaesthetization in a $1 \%$ solution of tricaine methasulphonate (MS-222). The gonads were removed, cut into small fragments, and fixed in 3\% glutaraldehyde in a phosphate buffer ( $\mathrm{pH} 7.4)$ overnight. The material was postfixed in $1 \%$ osmium tetroxide in the same buffer and dehydrated in graded alcohol. A small testis sample was embedded in Epon 812. Ultra-thin sections were contrasted with uranyl acetate and lead citrate and were later examined under a JEOL JEM-100SX transmission electron microscope.

\section{Results}

\section{Spermiogenesis}

The stages of spermatids in P. interruptus were identified as early, medium or advanced according to the state of chromatin, location of the centriolar complex in relation to the nucleus, the formation of the flagellum and rotation of the nucleus. The nuclei of early spermatids possess heterogeneous chromatin and are surrounded by a wide zone of cytoplasm containing spherical to elliptical mitochondria and centrioles in a perpendicular arrangement (Fig. 1).

The next stage is characterised by the beginning of flagellum formation and the dislocation of the centriolar complex from the periphery of the cell to a position adjacent to the nucleus. At this time, a depression begins to appear in the nuclear contour near the proximal centriole forming the future nuclear fossa. The distal centriole differentiates into the basal body and remains associated with the plasma membrane. The developing flagellum runs in the cytoplasmic canal, i.e. the space between the flagellar membrane and plasmalemma of the canal (Fig. 2). The chromatin is finely fibrous in nearly the entire volume of the nucleus except for the electron lucent area (Fig. 2).

At the medium stage, the flagellum and cytoplasmic canal undergo extension and the nucleus starts to rotate anterior to the centriolar complex, forming a deep indentation for the proximal centriole (Fig. 3). Nuclear chromatin starts to condense irregularly, with electron lucent and electron dense areas appearing within the nucleus. Most mitochondria are distributed at the basal pole of the nucleus, where the main mass of cytoplasm surrounds the cytoplasmic canal. In the course of differentia- 

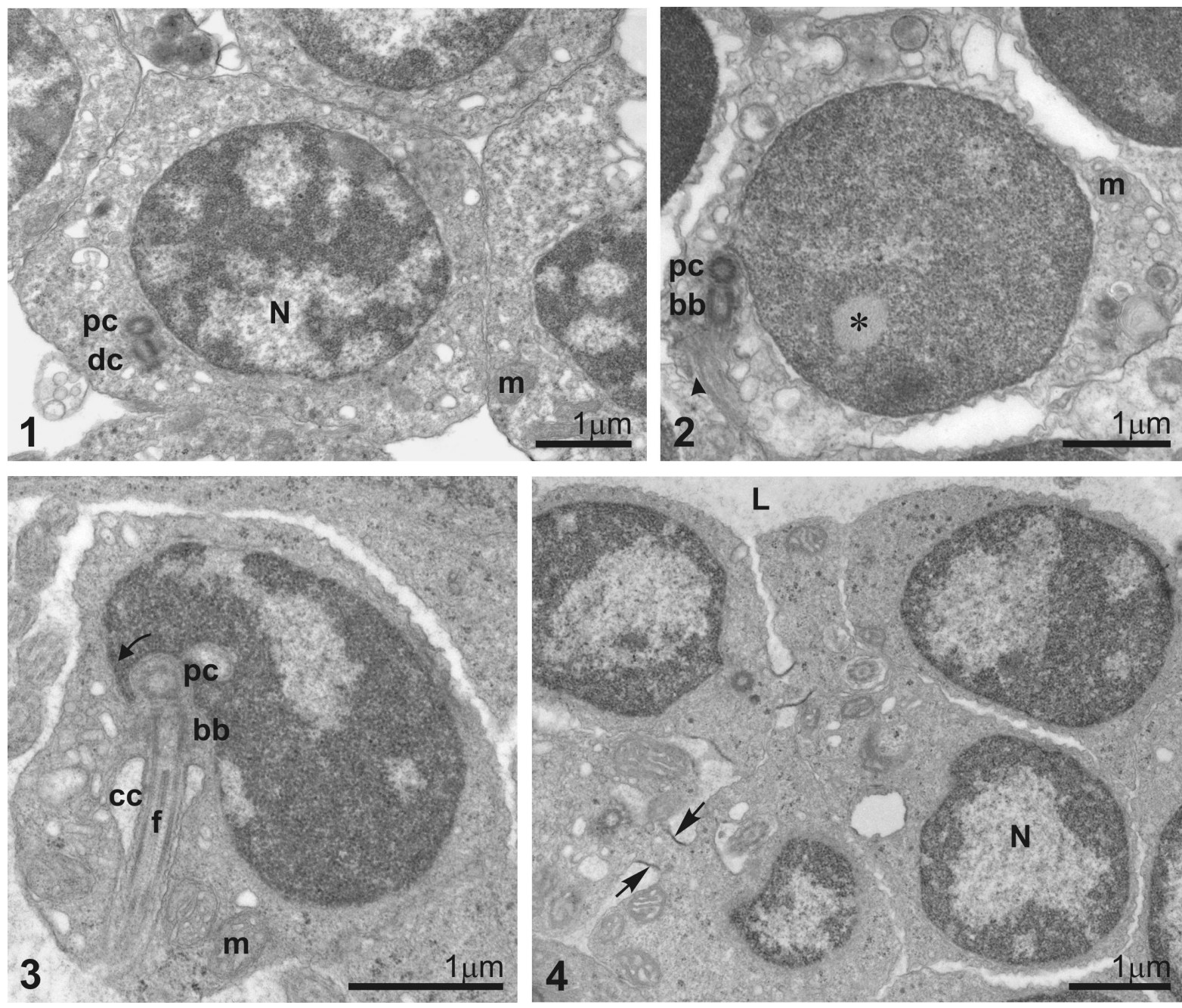

Figs 1-4. Spermiogenesis stages in early spermatids of $P$. interruptus. Fig. 1. Early spermatids have nuclei with heterogeneous chromatin; mitochondria and the centriolar complex are located in a wide layer of cytoplasm. Fig. 2. A spermatid at the beginning of flagellum and cytoplasmic canal formation. The nucleus possesses an electron lucent area. Fig. 3. A spermatid during rotation of the nucleus above the centriolar complex. The proximal part of the newly formed flagellum lays within the cytoplasmic canal. Fig. 4. Eearly spermatids within the cyst connected by a cytoplasmic bridge. arrow - the direction of nuclear rotation, arrowhead - cytoplasmic canal, bb - basal body, cc-cytoplasmic canal, dc - distal centriole, $\mathrm{f}$ - flagellum, $\mathrm{L}$ - lumen within the cyst, $\mathrm{N}$ - nucleus, $\mathrm{m}$ - mitochondrion, pc - proximal centriole, ${ }^{*}$ - electron lucent area.

tion spermatids are still interconnected by cytoplasmic bridges (Figs 4 \& 8).

In the final stage of nuclear rotation, the centriolar complex and flagellum are arranged coaxially. Mitochondria are located at the base of the nucleus around the cytolasmic canal (Fig. 5). The nuclear fossa at this stage contains only the proximal centriole, while the distal centriole lays at the base of the nucleus; both centrioles are encompassed by osmiophilic material, but it is more electron dense around the basal body (Figs 6-7).

In advanced spermatids, when rotation is complete, the nuclear fossa is deeper, bell-shaped in longitudinal sections and contains the entire proximal centriole and the most anterior part of the distal one (Fig. 8). The cytoplasm around the anterior and lateral parts of the nucleus is thin and devoid of organelles. Mitochondria are distributed within the long cytoplasmic collar surrounding the flagellum (Figs $8 \& 10$ ). The most posterior portion of the collar is devoid of any organelles and forms the cytoplasmic sleeve (Fig. 9). Nuclear chromatin is highly compact in most of the nucleus, except for an electron lucent area observed peripherally (Fig. 8 ) and extending from the region of nuclear fossa containing the proximal centriole area (Fig. 9). The flagellar axoneme has a typical microtubular pattern 9x2 + 2 (Figs 9-10).

The elimination of the excess of cytoplasm and membrane in the form of multivesicular and multilamellar bodies is observed not only in spermatids within the spermatocysts at the end of spermio- 

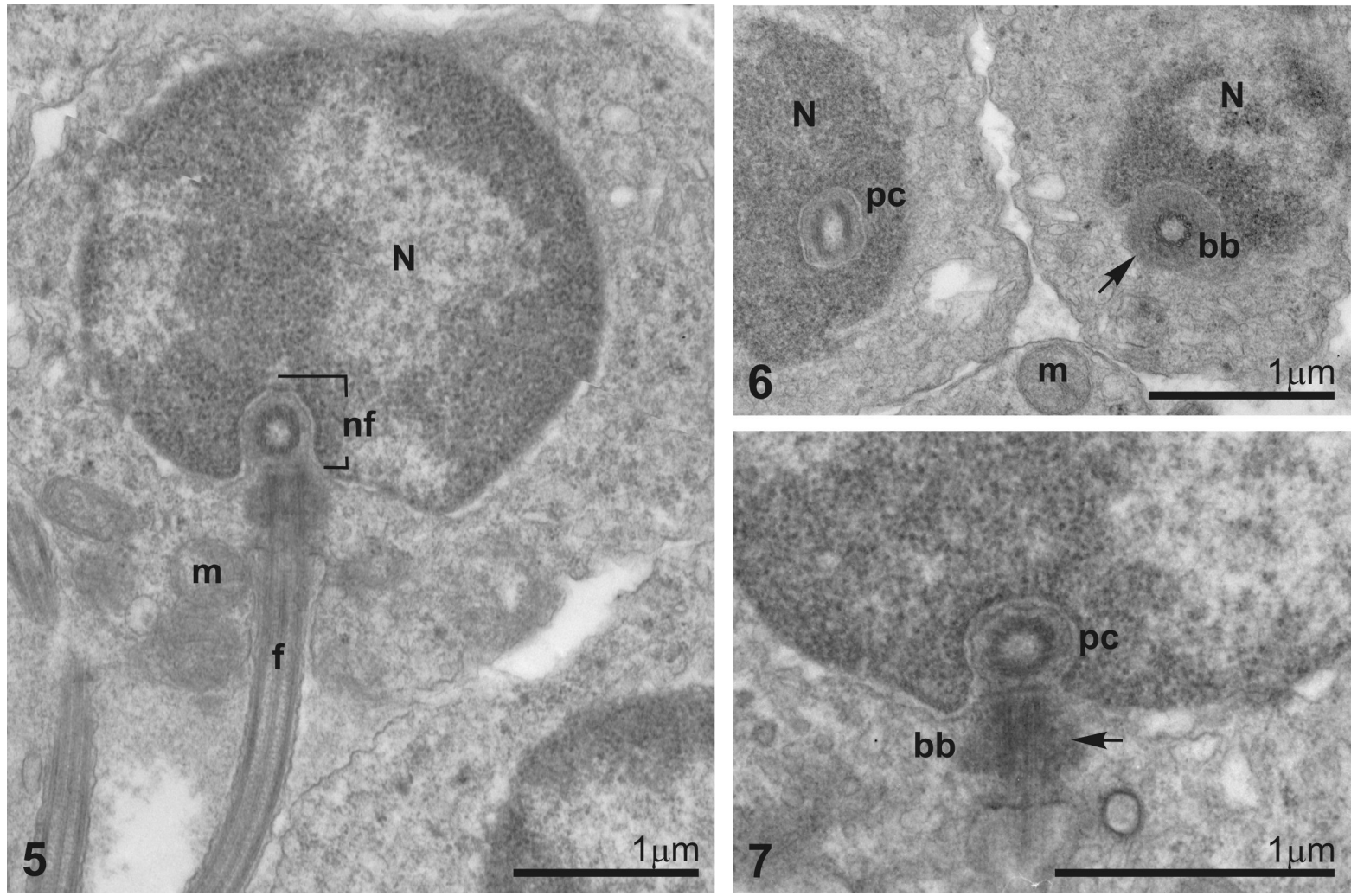

Figs 5-7. Spermatids in P. interruptus after nuclear rotation. Fig. 5. Longitudinally sectioned spermatid after rotation with nucleus, centriolar complex, flagellum and midpice in one axis. Mitochondria are located at the base of the nucleus in the cytoplasm forming the cytoplasmic collar around the anterior part of the flagellum. Fig. 6. Fragments of two transversally sectioned spermatids at the level of the proximal centriole located in nuclear fossa extending into the nuclear notch, and at the level of the basal body surrounded by osmiophilic material. Fig. 7. Longitudinally sectioned proximal centriole in nuclear fossa and basal body located at the base of nucleus and surrounded by osmiophilic material. arrow - osmiophilic material, bb - basal body, $\mathrm{f}$ - flagellum, $\mathrm{m}$ - mitochondrion, $\mathrm{N}$ - nucleus, $\mathrm{nf}$ - nuclear fossa.

genesis, but also continues in spermatozoa after spermiation into the lumen of the seminiferous tubules (Fig. 11).

\section{Spermatozoon structure}

The spermatozoon of $P$. interruptus consists of an anacrosomal head, midpiece and tail. The head is composed of a spherical nucleus about $2 \mu \mathrm{m}$ in diameter, containing highly electron dense chromatin with an electron lucent area located near the centre of the nucleus (Fig. 12). The posterior part of the nucleus has an axial nuclear fossa which is about $0.6 \mu \mathrm{m}$ deep, connecting with the electron lucent area near the proximal centriole and thus forming a nuclear notch (Fig. 3). The nuclear fossa is bell-shaped in longitudinal sections, circular in transverse sections, and contains the entire proximal centriole and the anteriormost part of the distal one. The centrioles are mutually perpendicular and embedded in an electron dense fibrous material (Figs 14-15). The cytoplasm located at the base of the nucleus contains mitochondria and many vesicles of various diameters. This portion forms the midpiece surrounding the cytoplasmic canal, containing the flagellum (Figs 14-16). Posterior to the cytoplasmic canal, the flagellum contains several membranous compartments located lateral to the axoneme and formed by elongate vesicles interspersed with narrow strips of cytoplasm (Fig. 17). The axoneme has the typical pattern $9 \times 2+2$, with no intratubular differentiation (Fig. 18).

\section{Discussion}

Spermatozoa that undergo nuclear rotation, such as that of $P$. interruptus, typically possess a nuclear fossa containing the proximal centriole and the main part of the basal body; the flagellum is located symmetrically and perpendicular to the base of the nucleus. Spermatozoa formed during spermiogenesis in this way were termed by MATTEI (1970) as Type I aquasperm and are present in other alestid species, in most externally fertilizing Characiformes (ROMAGOSA et al. 1999; QUAGIOGRASSIOTTO et al. 2003; VERISSIMO-SILVEIRA et al. 2006), as well as in representatives of Cyprinifor- 



Figs 8-11. A spermatid in P. interruptus during chromatin condensation and elimination of an excess of cytoplasm. Fig. 8 . Longitudinally sectioned spermatid with nucleus containing highly condensed chromatin as well as a pale area at the periphery and elongate future midpiece with mitochondria and vesicles enclosed in the cyst formed by projections of the Sertoli cells. Fig. 9. Transversally sectioned spermatids with proximal centriole within the nuclear fossa extending into the nuclear notch and flagellum in the cytoplasmic sleeve. Fig. 10. Transversally sectioned midpiece with mitochondria and eliminated multivesicular body. Fig. 11. Spermatozoa with multivesicular and multilamellar bodies in the lumen of the seminiferous tubules. Cs - cytoplasmic sleeve, $\mathrm{f}$ - flagellum, $\mathrm{L}$ - lumen of the seminiferous tubules, $\mathrm{m}$ - mitochondria, $\mathrm{ml}-$ multilamellated body, mv - multivesicular structure, $\mathrm{pc}$ - proximal centriole, $\mathrm{Sc}$-Sertoli cell, ${ }^{*}$ - electron lucent area. 


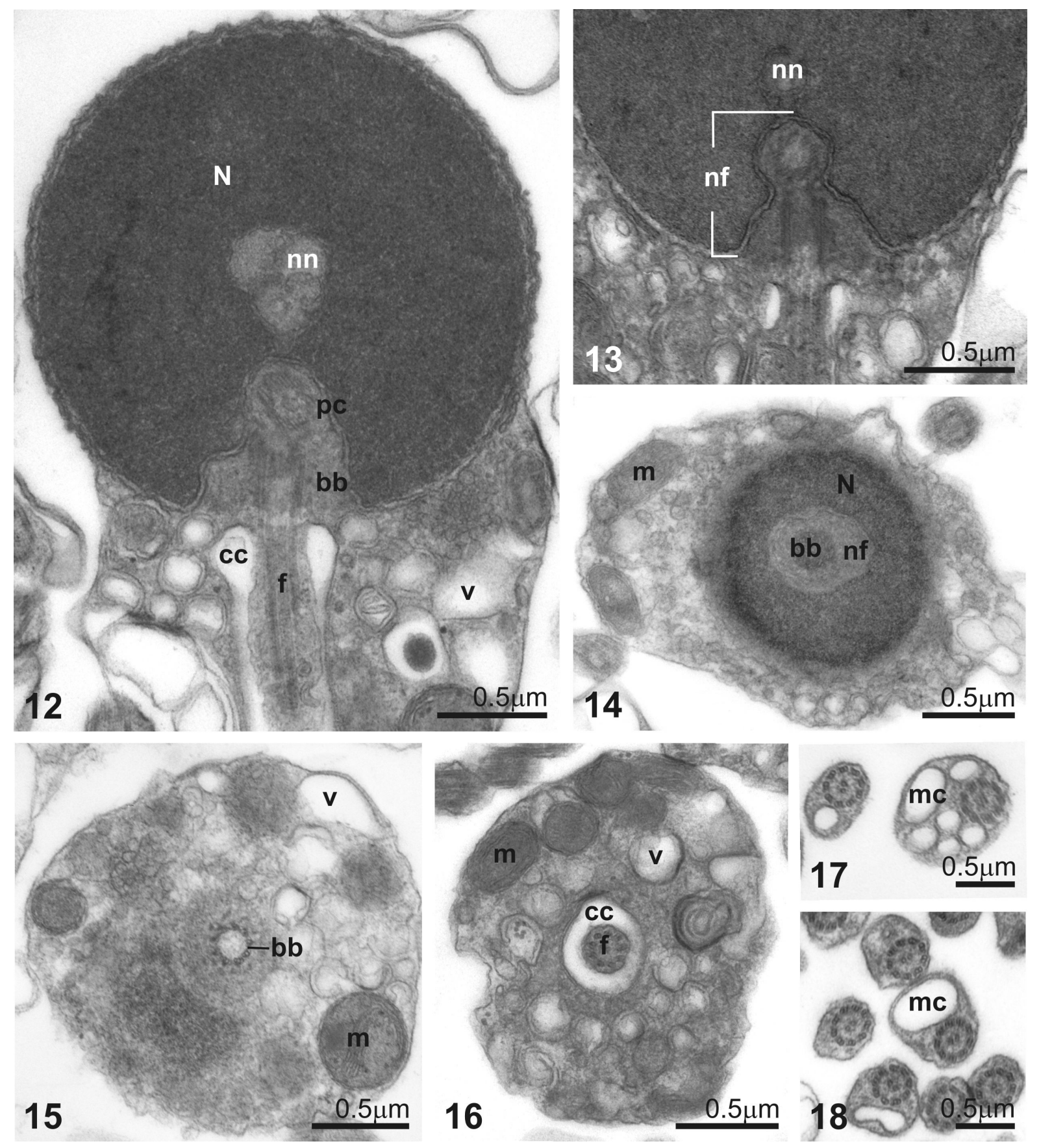

Figs 12-18. Structure of the spermatozoon in P. interruptus. Fig. 12. Head and midpiece of the spermatozoon in P. interruptus. The nuclear fossa containing centrioles and extending into the nuclear notch is located at the base of the nucleus. Midpiece with mitochondria and vesicles located in the cytoplasmic collar embracing the initial part of the flagellum running in the cytoplasmic canal. Fig. 13. The base of the nucleus with perpendicularly arranged centrioles in the nuclear fossa. Fig. 14. The anterior part of the transverse-sectioned basal body in the nuclear fossa. Fig. 15. The posterior part of the transverse-sectioned basal body behind the nucleus. Fig. 16. Transversally sectioned midpiece with mitochondria $(\mathrm{m})$ and vesicles surrounding the flagellum in the cytoplasmic canal. Figs 17-18. Transversally sectioned flagellar axoneme with laterally located membranous compartments. $\mathrm{bb}$ - basal body, cc - cytoplasmic canal, $\mathrm{f}$ - flagellum, $\mathrm{m}-$ mitochondria, $\mathrm{N}$ - nucleus, $\mathrm{nf}-\mathrm{nuclear}$ fossa, $\mathrm{nn}-$ nuclear notch, $\mathrm{m}$ - mitochondrion, mc - membranous compartment, $\mathrm{pc}$ - proximal centriole, $\mathrm{v}$ - vesicles.

mes (BACCETTI et al. 1984; GUAN \& AFZELIUS 1991 ) and Siluriformes (POIRER \& NICHOLSON 1982; JAMIESON 1991; QUAGIO-GRASSIOTTO \& CARVALHO 2000; SHAHIN 2006b) - the other orders of otophysan fishes (FINK \& FINK 1996).

There are also two types of spermatozoa that develop without nuclear rotation during spermiogene- sis among the externally fertilizing Characiformes. The first type, resembling Type II aquasperm sensu MATTEI (1970), was described in Acestrorhynchus falcatus, (Acestrorhynchidae) (MATOS et al. 2000) and in Nannostomus unifasciatus (Lebiasinidae) (VERISSIMO-SILVEIRA 2007; BURNS et $a l$. in press). In spermatozoa of these species, the 
flagellum is located laterally to the spherical nucleus, as in most early spermatids of teleost fishes. The second type, corresponding to novel Type III aquasperm sensu QUAGIO-GRASSIOTTO \& OLIVEIRA (2008) was described to date only in two characiform species: $N$. digrammus and $N$. marginatus (VERISSIMO- SILVEIRA 2007). In Type III aquasperm, the flagellar axis is perpendicular to the nucleus in early spermatids and remains in this position in spermatozoa.

In $A$. dentex and $P$. interruptus, after complete nuclear rotation $\left(90^{\circ}\right)$, the nuclear fossa, centrioles and the flagellum are located centrally and form the long axis of the spermatozoon. Complete rotation and a nuclear fossa of moderate length (less than one half of the nuclear diameter as in P. interruptus), or longer (equal to or more than half of the diameter of the nucleus as in $A$. dentex) are also present in other characiform species such as Chilodus punctatus (Anostomidae) (PECIO 2003), Brycon cephalus, B. orbignyanus and Salminus brasiliensis (Characidae) (ROMAGOSA et al. 1999; VERISSIMO-SILVEIRA et al. 2006). However in many other characiform species, the nuclear fossa is slightly eccentrically positioned due to incomplete rotation (less than $90^{\circ}$ ), sometimes is relatively shallow and contains mostly a part of one or of both centrioles, as exemplified by some characid species, e.g. Paracheirodon (=Hyphessobrycon) innesi (JAMIESON 1991), the erythrinid Hoplias malabaricus (Erythrinidae) (QUAGIO-GRASSIOTTO et al. 2001a), and Hemigrammus erythrozonus (PECIO et al. 2007).

In all studied alestid species the centrioles lay in nuclear fossa and are arranged perpendicularly to one another while the proximal centriole lays anterior to the basal body. A perpendicular arrangement of centrioles was described in spermatozoa of the most primitive genera of Characidae including B. cephalus (ROMAGOSA et al. 1999) and S. brasiliensis (VERISSIMO- SILVEIRA et al. 2006), which suggests that this state may have been present in the ancestors of many characiform families, especially since this type of centriole arrangement is also present in Chilodus punctatus (PECIO 2003), in some curimatid species such as Cyphocharax modestus and C. gillii (QUAGIO-GRASSIOTTO et al. 2003), and in Diplomystes mesembrinus from the family Diplomystidae, the most basal siluriforms (QUAGIO-GRASSIOTTO et al. 2001b).

However, the spatial relationship of the centrioles in various characiform representatives exhibits considerable variation even in a single family, but may be specific for subfamilies, and even species (JAMIESON 1991; BURNS et al. 1998; PECIO et al. 2005, 2007). This conclusion shows that a phylogenetic revision is needed for species in this diverse and species-rich family, for which ultrastructural characters of spermatozoa may also be of use.
The cytoplasmic collar around the initial part of the flagellum present in $A$. dentex and $P$. interruptus is rather short and does not extend into the cytoplasmic sleeve. In spermatozoa of both alestid species, the initial segment of the flagellum runs in the cytoplasmic canal, but in $A$. dentex a dense, fibrous membrane is present in close vicinity to the flagellar plasma membrane, which separates the midpiece from the cytoplasmic canal. This structure is absent in P. interruptus, but it seems identical to the several membranous concentric rings described in spermatozoa of Brycon and Salminus (VERISSIMO-SILVEIRA et al. 2006). The midpiece of $A$. dentex is devoid of any vesicles, which are abundant in $P$. interruptus. The vesicles in $P$. interruptus spermatozoa are of different diameter, some are only slightly smaller than mitochondria, and some are very small and linked to one another. The latter are similar to the unusual structure called the "lattice tubule" in spermatozoa of Citharinus sp. (MATTEI et al. 1995). The function of this structure is unknown, but it cannot be excluded that it participates in the elimination of excess cytoplasm.

Membranous compartments, peculiar structures of the flagellum in P. interruptus, mainly occur in the part running behind the cytoplasmic canal, while the flagellum in A. dentex does not possess these structures at all. Membranous structures located along the long axis of the medial portion of the flagellum were found in $H$. malabaricus and some curimatid species, where they occur laterally to the axoneme or surround it (QUAGIO-GRASSIOTTO et al. 2001a, 2003). Also in B. cephalus and B. microlepis, the initial portion of the flagellum possesses some vesicles in its cytoplasm (ROMAGOSA et al. 1999; VERISSIMO-SILVEIRA et al. 2006).

The similarities in the process of spermiogenesis and the fine structure of spermatozoa with axial nuclear fossa containing centrioles arrranged in the same pattern seen in both alestid species supports the hypothesis that the arrangement of the major organelles in spermatozoa of species in the same family is similar (BACCETTI et al. 1984). However, the spermatozoa possess species-specific characters. For example, spermatozoa in A. dentex have deep nuclear fossa and possess a dense, fibrous membrane separating the midpiece from the cytoplasmic canal (SHAHIN 2006a). Nonetheless, both alestid species possess a peculiar structure, a nuclear notch - the extension of the nuclear fossa filled with some fibrous material. A similar structure was described only in C. punctatus among Characiformes, and in some perciformes (PECIO 2003; GWO et al. 1993).

The spermatozoa of $A$. dentex and $P$. interruptus are of the primitive type and in many respects are very similar to those described for Brycon and 
Salminus. These data support the relationship among Characiformes proposed by ORTI and MEYER (1977) in which Brycon and Salminus form the sister group to the clade containing of Alestidae. This is not in opposition to the relationships proposed by BUKUP (1998), suggesting that Alestidae is the sister group to Characidae, which in turn is a basal group for the clade containing Acestrorhynchidae, Erythrinidae, Lebiasinidae, Hepsetidae and Ctenolucidae.

\section{Acknowledgements}

I wish to thank to Professor Dr. J. R. BURNS for revision of the manuscript and to Dr. D. PODKOWA for advice in preparing the plates. I also thank the staff of the Department of Histology and Cytology of the Jagiellonian University for providing electron microscope facilities.

\section{References}

ANDRADE R. F., BAZZOLI N. RIZ7O E. SATO Y. 2001. Continuous gametogenesis in the Neotropical freshwater teleost, Brycon affinis (Pisces: Characidae). Tissue and Cell 33: 524-532.

BACCETTI B. 1991. Comparative Spermatology 20 years after. Raven Press, New York.

BaCCETti B., Burrini A. G., CAllaini G., Gilbertini G., MAZZINI M., ZERUNIAN S. 1984. Fish germinal cells. I. Comparative spermatology of seven cyprinid species. Gamete Research 10: 373-396.

BUKUP P. A. 1998. Relationship of the Characidiinae and phylogeny of the characiform fishes (Teleostei: Characiformes (In: Phylogeny and Classification of Neotropical Fishes L. B. Malabarba, R. E. Reis, R. P. Vari, Z. M. S. Lucena \& C. A. S. Lucena eds. Porto Alegre, Edipucrs): 193-234.

BURNS J. R., WEITZMAN S. H. 2005. Insemination in ostariophysan fishes. (In: Viviparous Fishes. H. J. Grier \& M. C. Uribe eds. New Life Publications, Homestead Florida): 107-134.

Burns J. R., WeitzMan S. H., Grier H. J., MEnezes N. A 1995. Internal fertilization, testis and sperm morphology in glandulocaudinae fishes (Teleostei: Characidae: Glandulocaudinae). J. Morphol. 224: 131-145.

BURNS J. R., WeitZMAN S. H., LANGE K. R., MALABARBA L. R. 1998. Sperm ultrastructure in characid fishes (Teleostei, Ostariophysi). (In: Phylogeny and Classification of Neotropical Fishes. L. B. Malabarba, R. E. Reis, R. P. Vari, Z. M. S Lucena \& C. A. S. Lucena eds. Porto Alegre, Edipucrs): 235-244.

BuRnS J. R., QUAGIO-GRASSIOTTO I., JAMIESON B. G. M. (In press). Ultrastructure of Spermatozoa: Ostariophysi. (In: Reproductive Biology and Phylogeny of Fishes. Vol. I., B G. M. Jamieson ed. Science Publishers, Enfield, NH, USA and Plymouth, UK).

Calcagnotto D., Schaefer S. A., DE SAlle R. 2005. Relationships among characiform fishes inferred from analysis of nuclear and mitochondrial gene sequences. Mol. Phylogenet. Evol. 36: 135-153.

FINK S. V., FINK W. L. 1996. Interrelationships of the Ostariophysan fishes (Teleostei). (In: Interrelationships of Fishes. M. Stiassny, L. R. Parenti \& G. D. Johnson eds. San Diego Academic Press): 209-249.

GERY J. 1977. Characoids of the World. Tropical Fish Hobbyist Publications, Neptune City, New Jersey.
GREenwoOd H. H., Rosen D. E., WeitzMAn S. H., MYERS G. S. 1966. Phyletic studies of teleostean fishes with a provisional classification of living forms. Bull. Am. Mus. Nat. His. 131: 339-456.

GuAN T. L., AfZELIUS B. A. 1991. The spermatozoon of the Chinese bitterling, Rhodeus sericeus sinensis (Cyprinidae, Teleostei). J. Submicrosc. Cytol. Pathol. 23: 351-356.

Gwo J. C., Gwo H. H., ChANG S. L. 1993. Ultrastructure of the spermatozoon of the teleosts fish Acanthopagrus schlegeli (Perciformes: Sparidae). J. Morphol. 216: 29-33.

JAMIESON B. G. M. 1991. Fish Evolution and Systematics: Evidence from Spermatozoa. Cambridge, Cambridge University Press: 1-319.

LAHNSTEINER F., PATZNER R. A. 2008. Sperm morphology and ultrastructure in fish. (In: Fish Spermatology. S. M. H. Alavi, J. J. Cosson, K. Coward \& G. Raffiee eds. Alpha Science International Ltd. Oxford UK): 1- 61.

Matos E., Matos P., CorRal L., AZEVEdo C. 2000. Estrutura fina do espermatozóide de Acestrorhynchus falcatus Bloch (Teleostei, Characidae) da regio norte Brasil. Rev. Brasil. Zool. 17: 747-752

MATTEI X. 1970. Spermiogenese comparee des poisons. (In: Comparative Spermatology. B. Baccetti ed. Academic Press, New York): 57-69.

MATTEI X. 1988. The flagellar apparatus of spermatozoa in fish. Ultrastructure and evolution. Biol. Cell 63: 151-158.

MATTEI X. 1991. Spermatozoon ultrastructure and its systematic implications in fishes. Can. J. Zool. 69: 3038-3055.

Mattei X., Marchand B., Thiaw O. T. 1995. Unusual midpiece in the spermatozoon of the teleost fish, Citharinus sp. J. Submicrosc. Cytol. Pathol. 27: 189-191.

NELSON J. S. 1994. Fishes of the World. John Wiley \& Sons, Inc. New York.

ORTI G., MEYER A. 1977. The radiation of characiform fishes and the limits of resolution of mitochondrial ribosomal DNA sequences. Syst. Biol. 46: 75-100.

PECIO A. 2003. Spermiogenesis and fine structure of the spermatozoon in a Headstander, Chilodus punctatus (Teleostei, Characiformes, Anostomidae). Folia biol. (Kraków) 51: 55-62.

PECIO A., RAFIŃSKI J. 1999. Spermiogenesis in Mimagoniates barberi (Teleostei, Ostariophysi, Characidae), an oviparous, internally fertilizing fish. Acta Zool. 80: 35-45.

Pecio A., Burns J. R., Weitzman S. H. 2005. Sperm and spermatozeugma ultrastructure in the inseminating species Tyttocharax cochui, T. tambopatensis and Scopaeocharax rhinodus (Pisces:Teleostei: Characidae: Glandulocaudinae: Xenurobryconini). J. Morphol. 263: 216-226.

Pecio A., Burns J. R., Weitzman S. H. 2007. Comparison of spermiogenesis in the externally fertilizing Hemigrammus erythrozonus, Durbin 1909 and the inseminating Corynopoma riisei, Gill 1858 (Teleostei: Characiformes: Characidae). Neotropical Ichthyol. 4: 457-470.

POIRIER G. R., NICHOLSON N. 1982. Fine structure of the testicular spermatozoa from the channel catfish, Ictalurus punctatus. J. Ultrastruct. Res. 80: 104-110.

Quagio-GrassiotTo I., CARVALHo E. D. 2000. Ultrastructure of Sorubim lima (Teleostei, Siluriformes, Pimelodidae) spermiogenesis. J. Submicrosc. Cytol. Pathol. 32: 629-633.

QuAgio-GrassiotTo I., Oliveira C. 2008. Sperm ultrastructure and a new type of spermiogenesis in two species of Pimelodidae with a comparative review of sperm ultrastructure in Siluriformes. Zool. Anz. (In press).

Quagio-Grassiotto I., Negrao J. N. C., CARVAlho E. D., FORESTI F. 2001a. Ultrastructure of spermatogenic cells and spermatozoa in Hoplias malabaricus (Teleostei, Characiformes, Erythrinidae). J. Fish Biol. 59: 1494-1502.

Quagio-Grassiotto I., Oliveira C., Gosztonyi A. E. $2001 \mathrm{~b}$. The ultrastructure of spermiogenesis and spermatozoa in Diplomystes mesembrinus. J. Fish Biol. 58: 1623-1632. 
Quagio-Grassiotto I., Gameiro M. C., Schneider T., MALABARBA L. R., OliVEIRA C. 2003. Spermiogenesis and spermatozoa ultrastructure in five species of the Curimatide with some considerations on spermatozoal ultrastructure in the Characiformes. Neotropical Ichthyol. 1: 35-45.

Romagosa E., Narahara M. Y., Borelia M. I., ParREIRA S. F., FENERICH-VERANI N. 1999. Ultrastructure of the germ cells in the testis of matrinxă, Brycon cephalus (Teleostei, Characidae). Tissue and Cell 31: 540-544.

SHAHIN A. A. B. 2006a. Spermatogenesis and spermatozoon ultrastructure in the Nile Pebblyfish Alestes dentex (Teleostei: Characiformes: Alestidae) in Egipt. World J. Zool. 1: $1-16$.

SHAHIN A. A. B. 2006b. Semicystic spermatogenesis and biflagellate spermatozoon ultrastructure in the Nile electric catfish Malapterurus electricus (Teleostei: Siluriformes: Malapteruridae). Acta Zool. 87: 215-227.

VARI R. P. 1979. Anatomy, relationships and classification of the families Citharinidae and Distichodontidae (Pisces,
Characoidea). Bull. British Mus. (Natural History), Zoology 36: 261-344.

VERISSIMO-SILVEIRA R. 2007. Estudo filogenetico da sub-ordem Characoidei (Teleostei, Ostariophysi,Characiformes): com base na ultraestrutura dos espermatozóides. Ph. D. Thesis, Universidade Estadual Paulista, Botucatu.

VERISSIMO-SILVEIRA R., GUSMAO-POMPIANI P., VICENTINI C. A., Quagio-GrassiotTo I. 2006. Spermiogenesis and spermatozoa ultrastructure in Salminus and Brycon, two primitive genera in Characidae (Teleostei: Ostariophysi: Characiformes) Acta Zool. 87: 305-313.

Weitzman S. H., Malabarba L. R. 1998. Perspectives about the phylogeny and classification of the Characidae (Teleostei: Characiformes). (In: Phylogeny and Classification of Neotropical Fishes. L. B. Malabarba, R. E. Reis, R. P. Vari, Z. M. S. Lucena \& C. A. S. Lucena eds. Porto Alegre, Edipucrs): 161-170.

Zanata A. M., VARi R. P. 2005. The family Alestidae (Ostariophysi, Characiformes): a phylogenetic analysis of a trans-Atlantic clade. Zool. J. Linn. Soc. 145: 1-144. 